\title{
OUTCOME OF PREGNANCY IN WOMEN WITH PREVIOUS CAESAREAN SECTION
}

\author{
Bellad Girija Channabasappa1, Rajendra Ramakrishna Godbole ${ }^{2}$
}

${ }^{1}$ Assistant Professor, Department of Obstetrics and Gynaecology, Belagavi Institute of Medical Sciences, Belagavi. ${ }^{2}$ Associate Professor, Department of Obstetrics and Gynaecology, Belagavi Institute of Medical Sciences, Belagavi.

\section{ABSTRACT}

\section{BACKGROUND}

Carefully selected cases of Vaginal Birth after Caesarean Section (VBAC) is safe and successful. Even though options of elective caesarean section or a trial of labour are given to women with prior caesarean section, the risk is always present. In successful VBACs, morbidity is less compared to repeat caesarean section. That is why this study is conducted to determine the outcome of pregnancy in women with previous CS.

\section{OBJECTIVES}

1. To evaluate the clinical course of labour in cases with previous caesarean section.

2. To study the perinatal outcome in cases with previous caesarean section either by vaginal delivery or repeat Caesarean section.

3. To study maternal morbidity in these cases.

\section{METHOD}

A retrospective analysis of medical records of 250 women with a previous caesarean section, who delivered in BIMS Hospital between May 2015 and July 2015 was carried out. Women with recurrent indications for caesarean section and those having nonrecurrent indications with any complicating factors in present pregnancy and women with previous two caesarean sections were not given trial for vaginal delivery. Those women with previous section for the non-recurrent indications were given trial for vaginal delivery.

\section{STATISTICAL ANALYSIS}

Was done by Chi-square test.

\section{RESULT}

In 250 cases, 132 cases were given trial for vaginal delivery. In these, vaginal delivery was $61.3 \%$ and repeat section was $38 \%$. There is an association between maternal morbidity and type of delivery. Birth weight was associated with the type of delivery. There is no association between neonatal outcome and type of delivery.

\section{CONCLUSION}

In carefully selected patients, appropriate timing and close supervision, trial of vaginal delivery in previous one caesarean section is safe and successful. Individual approach seems to be the best.

\section{KEYWORDS}

Previous Caesarean Section, Vagina Birth after Caesarean Section, Trial of Vaginal Delivery, Elective Repeat Section.

HOW TO CITE THIS ARTICLE: Channabasappa BG, Godbole RR. Outcome of pregnancy in women with previous caesarean section. J. Evolution Med. Dent. Sci. 2016;5(44):2750-2753, DOI: 10.14260/jemds/2016/642

\section{INTRODUCTION}

It is an attempt to analyse the existing trends in our hospital in management of patients with previous section in subsequent pregnancy. All obstetricians encounter increasing number of post caesarean pregnancy, because the number of primary caesarean section for non-recurrent causes is rapidly rising. The procedure is not simple and needs to be performed only when circumstances distinctly require it. ${ }^{1}$ For many years, the phrase 'Once a caesarean, always a caesarean' dictated

Financial or Other, Competing Interest: None.

Submission 19-04-2016, Peer Review 14-05-2016,

Acceptance 19-05-2016, Published 01-06-2016.

Corresponding Author:

Dr. Bellad Girija Channabasappa,

'Simply OM' Apartments,

GF-1, $2^{\text {nd }}$ Main, $6^{\text {th }}$ Cross,

Sadashiv Nagar,

Belagavi-590001,

Karnataka State.

E-mail: rajashekarphypub@gmail.com

DOI: $10.14260 /$ jemds/2016/642 obstetric practice. Later, because of increasing Caesarean Sections (CS) it was noted that vaginal birth after CS (VBAC) might help in reducing the rate of $\mathrm{CS}^{2}{ }^{2}$ In an appropriate clinical and proper selected group of women, VBAC is safe and effective. ${ }^{3,4}$

A trial of vaginal delivery after a previous CS is considered safer than the routine repeat CS, because operative risks are completely eliminated. The hospital stay is much shorter and expenses involved are much less. However, several factors increase the likelihood of failed trial, which in turn might lead to increased maternal and perinatal mortality and morbidity rates. $^{2}$ There is a controversy in the trial of vaginal delivery in post-caesarean pregnancy. This needs a critical audit.

So, informing and counseling the concerned women and their relatives regarding the benefits and risks involved in VBAC and repeat CS is essential. That is why this study is conducted to determine the outcome of pregnancy in women with previous CS in relation to vaginal delivery, maternal and perinatal complications, to identify the factors which can influence the outcome of trial of vaginal delivery. 


\section{METHODS}

A retrospective analysis of medical records of 250 women with previous CS from May 2015 to July 2015. Hospital records of patients with previous CS undergoing delivery in our hospital are collected.

The following women were not given trial of vaginal delivery, but were taken for caesarean section $(n=118)$

1. Women with recurrent indications for CS.

2. Those having non-recurrent indications with any complicating factors in present pregnancy.

3. Patient with previous two CS.

4. Mal-presentations.

5. Details of previous CS not available.

The following women $(n=132)$ were given trial vaginal delivery: i) Previous one CS for the non-recurrent indications; ii) Singleton pregnancy; iii) Gestation age more than 37 weeks; iv) History of one CS. According to the case record, labour was monitored by every half hourly maternal pulse, foetal heart rate and uterine contractions and $4^{\text {th }}$ hourly $\mathrm{BP}$, cervical dilation, descent of head and moulding. A close watch on the early recognition for scar dehiscence by identifying the maternal tachycardia, scar tenderness, foetal distress and vaginal bleeding. Attempt of vaginal delivery was abandoned if there was any suspicion of scar dehiscence or foetal distress or unsatisfactory progress of labour. Such women were taken for CS.

Institutional ethical clearance for the study was obtained on 05-10-2015.

\section{Statistical Analysis}

Qualitative data were analysed using Chi-square test $\left(\mathrm{X}^{2}\right) ; \mathrm{p}$ value less than 0.05 means statistically significant; $p$ value less than 0.001 means highly significant; $p$ value more than 0.05 is insignificant.

\section{RESULTS}

Out of the total of 250 patients who were included in the study, 132 were on trial vaginal delivery (52.8\%) and on 118 (47.2\%) patients' elective Caesarean section was done (Table 1).

Most of the women belonged to 20-25 years of age (183 cases, i.e. 73.2\%). Overall age group number of patients is not uniformly distributed among all the parameters. Most of the patients ( 213 cases, i.e. $85.2 \%$ ) were in the $37-40$ weeks of gestation. Here also number of patients are not uniformly distributed among both the groups, i.e. age and period of gestation groups (Table 2).

Women delivered vaginally in the trial group were 81, i.e. $61.36 \%$. In this trial group $50 \%$ had spontaneous vaginal delivery, $11.36 \%$ required outlet forceps either for prolonged $2^{\text {nd }}$ stage or foetal distress in $2^{\text {nd }}$ stage and $38.63 \%$ needed emergency LSCS (Table 3).

Foetal distress cases were 24 in number (47\%). The number of patients were not distributed uniformly among all the parameters. In 10 women scar tenderness was the indication, but during surgery 2 cases had scar dehiscence and in 1 case there was bladder rupture which was repaired (Table 4).

There was no maternal mortality. Morbidity like pyrexia, wound gaping, UTI, wound infection, bladder rupture and requirement of blood transfusion was more in repeat CS. Paraurethral tear, episiotomy wound gaping and cervical tear were common in VBAC group. There is association between maternal complication and type of delivery (Table 5).

There is an association between birth weight ( 2.6 to $4.0 \mathrm{~kg}$ ) and type of delivery (vaginal delivery, abdominal delivery). Among these, abdominal delivery is significantly higher than the vaginal delivery. So birth weight is associated with the type of delivery. There is no association between type of delivery (vaginal delivery and abdominal delivery) with living children, still births and neonatal deaths (Table 6).

The success rate of VBAC in our study is $61.36 \%$ (Table 7). Out of 250 cases, 81 cases (32.4\%) of cases delivered vaginally either spontaneously or by forceps and 169 cases (67.6\%) required caesarean section. Emergency caesarean section (51 cases) were less than elective caesarean section (118 cases who were not in labour). One case who underwent subtotal hysterectomy was diagnosed as ruptured uterus, since patient came late in labour (Table 8).

\begin{tabular}{|c|c|}
\hline Group & No. \\
\hline Trial vaginal delivery & $132(52.8 \%)$ \\
\hline Elective CS & $118(47.2)$ \\
\hline \multicolumn{2}{|c|}{$\begin{array}{c}\text { Table 1: A Total of 250 Patients } \\
\text { were Included in the Study }\end{array}$} \\
\hline
\end{tabular}

\begin{tabular}{|c|c|c|c|}
\hline Parameters & No. & Percentage & \\
\hline \multicolumn{4}{|l|}{ a. Age (Years) } \\
\hline $20-25$ & 183 & 73.2 & \multirow{4}{*}{$\begin{array}{c}\mathrm{X}^{2}= \\
32.82 \\
\mathrm{P}<0.001\end{array}$} \\
\hline $26-30$ & 53 & 21.2 & \\
\hline $31-35$ & 11 & 4.4 & \\
\hline 36 and above & 3 & 1.2 & \\
\hline \multicolumn{4}{|c|}{ b. Period of Gestation (Weeks) } \\
\hline $37-40$ & 213 & 85.2 & \multirow{2}{*}{$\begin{array}{c}\mathrm{X}^{2}= \\
123.900 \\
\mathrm{P}<0.001\end{array}$} \\
\hline$>40$ weeks & 37 & 14.8 & \\
\hline \multicolumn{4}{|c|}{ c. Indication for Previous Section } \\
\hline CPD & 105 & 42 & \\
\hline Foetal distress & 61 & 24.4 & \\
\hline Non-progress of labour & 24 & 9.6 & \\
\hline Mal-presentation & 21 & 8.4 & \\
\hline Severe PIH/ Eclampsia & 10 & 4 & \\
\hline $\mathrm{APH}$ & 7 & 2.8 & \\
\hline Failed induction & 10 & 4 & \\
\hline Obstructed labour & 8 & 3.2 & \\
\hline $\mathrm{BOH}$ & 4 & 1.6 & \\
\hline \multicolumn{4}{|c|}{ Table 2: Demographic Profile $(n=250)$} \\
\hline
\end{tabular}

\begin{tabular}{|c|c|c|}
\hline Mode of Delivery & No. & Percentage \\
\hline Spontaneous vaginal delivery & 66 & 50 \\
\hline Instrumental & 15 & 11.36 \\
\hline Unsuccessful vaginal delivery & 51 & 38.63 \\
\hline \multicolumn{2}{|c|}{$\mathrm{X}^{2}=31.23 ; \mathrm{p}<0.001$} \\
\hline Table 3: Outcome Trial of Labour in \\
Present Pregnancy (n= 132)
\end{tabular}

\begin{tabular}{|c|c|c|}
\hline $\begin{array}{l}\text { Indication for Repeat } \\
\text { Emergency CS (n=51) }\end{array}$ & No. & Percentage \\
\hline Foetal distress & 24 & 47.05 \\
\hline Non-progress of labour & 13 & 25.49 \\
\hline Obstructed labour & 3 & 5.88 \\
\hline Scar tenderness & 10 & 19.6 \\
\hline Abruptio placenta & 1 & 1.96 \\
\hline \multicolumn{2}{|c|}{$\mathrm{X}^{2}=32.82 ; \mathrm{p}<0.001$} \\
\hline \multicolumn{2}{|c|}{ Table 4: Indication for Repeat Emergency CS } \\
\hline
\end{tabular}




\begin{tabular}{|c|c|c|c|c|}
\hline \multirow[t]{2}{*}{$\begin{array}{c}\text { Type of } \\
\text { Complications }\end{array}$} & \multicolumn{2}{|c|}{$\begin{array}{l}\text { Vaginal } \\
\text { Delivery } \\
(n=81)\end{array}$} & \multicolumn{2}{|c|}{$\begin{array}{c}\text { Repeat CS } \\
(n=169)\end{array}$} \\
\hline & No & $\%$ & No & $\%$ \\
\hline Pyrexia & 3 & 3.7 & 15 & 8.87 \\
\hline $\mathrm{PPH}$ & 1 & 1.23 & 2 & 1.18 \\
\hline Wound gaping & -- & -- & 5 & 2.96 \\
\hline Cervical tear & 1 & 1.23 & -- & -- \\
\hline Paraurethral tear & 2 & 2.46 & -- & -- \\
\hline $\begin{array}{l}\text { Episiotomy wound } \\
\text { gaping }\end{array}$ & 4 & 4.93 & -- & -- \\
\hline Blood transfusion & 1 & 1.23 & 3 & 1.77 \\
\hline UTI & 2 & 2.46 & 10 & 5.92 \\
\hline Wound infection & -- & -- & 5 & 2.96 \\
\hline Bladder rupture & -- & -- & 3 & 1.77 \\
\hline \multicolumn{5}{|c|}{$\mathrm{X}^{2}=26.87 ; \mathrm{p}<0.05$} \\
\hline
\end{tabular}

\begin{tabular}{|c|c|c|c|c|}
\hline $\begin{array}{l}\text { Birth } \\
\text { Weight } \\
\text { (Kg) }\end{array}$ & $\begin{array}{c}\text { Vaginal } \\
\text { Delivery }\end{array}$ & $\begin{array}{c}\text { Abdominal } \\
\text { Delivery }\end{array}$ & Total & Analysis \\
\hline $2.0-2.5$ & $\begin{array}{c}23 \\
(9.2 \%) \\
\end{array}$ & $\begin{array}{c}24 \\
(9.6 \%) \\
\end{array}$ & $\begin{array}{c}47 \\
(18.8 \%) \\
\end{array}$ & \multirow{4}{*}{$\begin{array}{c}\mathrm{X}^{2}= \\
12.99 \\
\mathrm{p}<0.02\end{array}$} \\
\hline $2.6-3.0$ & $\begin{array}{c}41 \\
(16.4 \%)\end{array}$ & $\begin{array}{c}80 \\
(32.0 \%)\end{array}$ & $\begin{array}{c}121 \\
(48.4 \%)\end{array}$ & \\
\hline $3.1-3.5$ & $\begin{array}{c}16 \\
(6.4 \%)\end{array}$ & $\begin{array}{c}50 \\
(20.0 \%)\end{array}$ & $\begin{array}{c}66 \\
(26.4 \%)\end{array}$ & \\
\hline $3.6-4.0$ & $\begin{array}{c}1 \\
(0.4 \%)\end{array}$ & $\begin{array}{c}15 \\
(6 \%)\end{array}$ & $\begin{array}{c}16 \\
(6.4 \%)\end{array}$ & \\
\hline $\begin{array}{c}\text { Living } \\
\text { children }\end{array}$ & $\begin{array}{c}79 \\
(97.53 \%) \\
\end{array}$ & $\begin{array}{c}166 \\
(98.22 \%) \\
\end{array}$ & $\begin{array}{c}245 \\
(98 \%) \\
\end{array}$ & \multirow{3}{*}{$\begin{array}{c}\mathrm{X}^{2}= \\
1.05 \\
\mathrm{p}>0.05\end{array}$} \\
\hline Still birth & 0 & $\begin{array}{c}1 \\
(0.56 \%)\end{array}$ & $\begin{array}{c}1 \\
(0.4 \%)\end{array}$ & \\
\hline $\begin{array}{c}\text { Neonatal } \\
\text { death }\end{array}$ & $\begin{array}{c}2 \\
(2.46 \%)\end{array}$ & $\begin{array}{c}2 \\
(1.18 \%)\end{array}$ & $\begin{array}{c}4 \\
(1.6 \%)\end{array}$ & \\
\hline
\end{tabular}

\begin{tabular}{|c|c|c|c|}
\hline Sl. No. & Author & Year & Percentage \\
\hline 1 & Yadav K. $^{5}$ & 2000 & $61.16 \%$ \\
\hline 2 & Pandey N. $^{6}$ & 2002 & $42 \%$ \\
\hline 3 & Dinsmoor MJ. $^{7}$ & 2007 & $76 \%$ \\
\hline 4 & Turner MJA. $^{8}$ & 2006 & $77.8 \%$ \\
\hline 5 & Chaudhari DR. $^{9}$ & 2012 & $67.0 \%$ \\
\hline 6 & Present Study & & $61.36 \%$ \\
\hline \multicolumn{4}{|c|}{ Table 7: Comparative Percentage Vaginal Delivery } \\
after Trial of Scar of Various Authors \\
\hline
\end{tabular}

This table shows VBAC range is $42 \%$ - $77.8 \%$. In our study, success rate is $61.36 \%$.

\begin{tabular}{|c|c|c|c|}
\hline $\begin{array}{l}\text { Sl. } \\
\text { No. }\end{array}$ & $\begin{array}{c}\text { Outcome in Present } \\
\text { Pregnancy }\end{array}$ & $\begin{array}{l}\text { No. of } \\
\text { Cases }\end{array}$ & Percentage \\
\hline \multirow{4}{*}{1} & \multicolumn{3}{|l|}{ Vaginal Delivery } \\
\hline & i. Normal & 66 & $26.4 \%$ \\
\hline & ii. Forceps & 15 & $6 \%$ \\
\hline & Total & 81 & $32.4 \%$ \\
\hline \multirow{4}{*}{2} & \multicolumn{3}{|l|}{ Abdominal Delivery } \\
\hline & $\begin{array}{l}\text { i. Elective caesarean } \\
\text { section }\end{array}$ & 118 & $47.2 \%$ \\
\hline & $\begin{array}{c}\text { ii. Emergency } \\
\text { caesarean section }\end{array}$ & 51 & $20.4 \%$ \\
\hline & Total & 169 & $67.6 \%$ \\
\hline \multicolumn{4}{|c|}{$\begin{array}{l}\text { Table 8: Outcome of Labour in } \\
\text { Post-Caesarean Section }(n=250)\end{array}$} \\
\hline
\end{tabular}

\section{DISCUSSION}

Women with prior CS require special care during both antenatal and labour. Before 1970, the term in Obstetric practice was 'once a Caesarean, always a Caesarean.' But now it is 'once a Caesarean, always a hospital delivery.'

The decision for a trial of labour or elective repeat CS is an individual one and that should be based on careful selection and thorough counselling. ${ }^{4}$ Maternal characteristics and Obstetric history can provide a rough estimate. Several studies suggest that for appropriately selected women with previous one CS, prior vaginal delivery, a trial for vaginal delivery is safe.

Studies by Yadav K. ${ }^{5}$ shows $67.16 \%$ vaginal delivery after trial of labour, Pandey N. ${ }^{6}$ shows $42.0 \%$, Dinsmoor MJ..$^{7}$ shows 76\%, Turner MJA. ${ }^{8}$ shows $77.8 \%$ and Chaudhari DR. ${ }^{9}$ shows $67 \%$. Our success rate is $61.36 \%$ and is comparable to studies by Yadav K. 5 and Chaudhari DR. ${ }^{9}$

\section{Mode of Delivery}

In modern obstetrics during second stage of labour, controversy exists regarding use of prophylactic forceps to reduce time. Some studies. 5,9 used prophylactic forceps during second stage labour to cut short the duration. In our study, prophylactic forceps was used in 9 cases $(6.81 \%)$.

Augmentation of labour using Oxytocin during trial of vaginal delivery in previous Caesarean section is controversial. Singhal P.10 achieved a success rate of $88 \%$; Iyer S et al ${ }^{11}$ found $69 \%$ using Oxytocin during trial of labour. In our study, the success rate using Oxytocin in trial of labour is $40.9 \%$.

\section{Foetal Distress}

Diagnosis of foetal distress was done by noting bradycardia (FSH $<100$ beats per minute), tachycardia (FSH $>160$ per minute) and meconium stained liquor. In studies by Yadav K. ${ }^{5}$, Chaudhari DR. ${ }^{9}$ and Shakti V. ${ }^{12}$, the foetal distress were $22.72 \%, 14.15 \%$ and $50 \%$ of cases respectively. In our study, the foetal distress was $47.05 \%$ of cases, which was comparable to study by Shakti V.12

\section{Scar Dehiscence}

It is defined as incomplete or complete separation of uterine scar with membrane intact and foetus in utero. Studies by Choudhari DR. ${ }^{9}$, Iyer S. ${ }^{11}$ and Shakti V.12 and the incidence of scar dehiscence was $5.66 \%, 0.5 \%$ and $1.44 \%$ respectively. In our study, the scar dehiscence was $1.5 \%$ and is comparable with Iyer S.11 Factors which have negative impact.2,13 are cases with labor induction, maternal obesity, maternal age $(>35$ yrs.), gestational age ( $>40$ weeks), birth weight ( $>4 \mathrm{kgs}$ ) and gap between 2 deliveries ( $<18$ months)

A history of previous success Vaginal Birth After Caesarean Section (VBAC) increases the likelihood of success with future attempts.14,15 The risk of uterine rupture is higher with an induced labour than with spontaneous labour with trial. Induction and augmentation with Oxytocin is safe in selected cases with standard Obstetric indications. But use of prostaglandins for induction need much caution.

Repeat CS and trial labour are both at risk. Maternal morbidity like pyrexia, atonic post-partum haemorrhage (PPH), urinary tract infection, wound gaping and need for blood transfusion are more common in repeat CS. Cervical tear, traumatic PPH and scar dehiscence are more common in 
trial of vaginal delivery. Our study shows an association between maternal complication and type of delivery.

\section{CONCLUSION}

Mode of delivery should be decided depending upon the previous indication, type of scar and associated maternal complications. An attempt for VBAC is well justified for post caesarean pregnancy with non-recurrent indication. Vaginal deliveries are safer than Caesarean section, as there are fewer complications with less maternal morbidity. The ability to predict women who are at high risks for failing the trial of vaginal delivery and those with high probability of successful delivery would help guide the clinician making good clinical decision. This would minimize adverse events.

The key factors to achieve greater degree of success in VBAC are proper selection, appropriate timing and close supervision by competent staff. By this we can eliminate the need for large proportion of repeat Caesarean section. Individualized approach for VBAC seems to be the best.

\section{ACKNOWLEDGEMENT}

The authors are thankful to the Director, BIMS, Belagavi, for giving us the permission and logistic support to conduct the study. We are grateful to all the patients for their kind cooperation in conducting the study. We also thank Mrs. Sunanda Halki, for her help in Statistical analysis and all the teaching and non-teaching staff for their help.

\section{REFERENCES}

1. Mukherjee SN. Rising caesarean section rate. J Obstet Gynaecol India 2006;56(4):298-300.

2. Chhabra S, Arora G. Delivery in women with previous caesarean section. J Obstet Gynaecol India 2006;56(4):304-7.

3. Tripathi JB, Doshi HU. Pattern of cervical dilatation in women with a previous caesarean section. J Obstet Gynaecol India 2005;55(2):125-7.
4. Shah SR, Prasad P. Outcome of labor in previous one lower segment caesarean section cases. Asian J Obstet Gynaecol Pract 2006;10:7-11.

5. Yadav K. Outcome of labour following previous lower segment caesarean section. J obst \& gyn India 2000;50:52-3.

6. Pandey N, Sharma C, Singhvi S. Maternal and fetal outcome in previous caesarean section. Obstet \& Gynaecol Today 2002; 7:144-6.

7. Dinsmoor MJ, Brock EL. Predicting failed trial of labour after primary caesarean delivery. Obst \& Gyn 2004;103(2):282-6.

8. Turner MJA, Agnew G, Langan H. Uterine rupture and labour after a previous low transverse caesarean section. Br J obst \& gyn 2006;113(6):729-32.

9. Chaudhari DR, Shinde SM. Clinical profile and outcome of labour in cases following previous caesarean section. Int J Health Sci Res 2012;2(9):1-12.

10. Singhal P. Role of oxytocin in cases of previous caesarean section. J obst \& gyn India 1992;42:155-60.

11. Iyer S, Handa PR, Basu SB. Delivery after one previous caesarean section-one year prospective study. J obst \& Gyn India 2001;51:51-4.

12. Shakti V, Behera RC, Sandhu GS, et al. Vaginal birth after caesarean delivery. J Obst \& Gyn India 2006;56(4):3203.

13. Hanley ML, Smulian JC, Lake MF, et al. Analysis of repeat caesarean delivery indications: implications of heterogeneity. Am J Obstet Gynaecol 1996;175(4 Pt1):883-8.

14. Caughey AB, Shipp TD, Repke JT, et al. Trial of labor after caesarean delivery: the effect of previous vaginal delivery. Am J Obstet Gynaecol 1998;179(4):938-41.

15. Gyamfi C, Juhasz G, Gyamfi P, et al. Increased success of trial of labor after previous vaginal birth after caesarean. Obstet Gynaecol 2004;104(4):715-9. 